\title{
The pro-inflammatory cytokine tumor necrosis factor a stimulates expression of the carnitine transporter OCTN2 (novel organic cation transporter 2) and carnitine uptake via nuclear factor-kB in Madin-Darby bovine kidney cells
}

\author{
X. Zhou, R. Ringseis, G. Wen, and K. Eder ${ }^{1}$ \\ Institute of Animal Nutrition and Nutrition Physiology, Justus-Liebig-Universität Gießen, Heinrich-Buff-Ring 26-32, D-35392 Gießen, Germany
}

\begin{abstract}
Carnitine uptake into tissues is mediated mainly by the novel organic cation transporter 2 (OCTN2), whose expression is upregulated in the liver of early-lactating dairy cows. It has been shown recently that pro-inflammatory cytokines, including tumor necrosis factor $\alpha(\mathrm{TNF} \alpha)$, stimulate OCTN2 expression and carnitine uptake in intestinal cells and inflamed intestinal mucosa. Given that many early-lactating dairy cows show typical signs of hepatic and systemic inflammation, such as elevated concentrations of circulating TNFo and activation of the key regulator of inflammation, nuclear factor $\kappa \mathrm{B}(\mathrm{NF}-\kappa \mathrm{B})$, in tissues, it is possible that upregulation of OCTN2 and increase of carnitine uptake by $\mathrm{TNF} \alpha$ is mediated by $\mathrm{NF}-\kappa \mathrm{B}$, a mechanism that might contribute to the upregulation of OCNT2 in the liver of early-lactating dairy cows. Thus, in the present study, we tested the hypothesis that $\mathrm{TNF} \alpha$ stimulates OCTN2 gene expression and carnitine uptake via NF- $\kappa \mathrm{B}$ in the bovine Madin-Darby bovine kidney (MDBK) cell line. Treatment with TNF $\alpha$ caused activation of NF- $\kappa \mathrm{B}$, increased the mRNA and protein concentration of OCTN2, and stimulated the uptake of carnitine in MDBK cells. In contrast, combined treatment of MDBK cells with TNFa and the NF- $\kappa \mathrm{B}$ inhibitor BAY 11-7085 completely blocked the effect of TNFo on OCTN2 mRNA and protein concentration and uptake of carnitine. These findings suggest that the bovine OCTN2 gene and carnitine uptake are regulated by NF- $\kappa \mathrm{B}$. Future studies are required to show the in vivo relevance of this regulatory mechanism in cattle.
\end{abstract}

Key words: carnitine uptake, novel organic cation transporter 2, nuclear factor- $\kappa \mathrm{B}$, dairy cow

\section{INTRODUCTION}

Carnitine is a water-soluble quaternary amine that is essential for normal function of all tissues. Carnitine

Received October 30, 2014.

Accepted March 13, 2015.

${ }^{1}$ Corresponding author: klaus.eder@ernaehrung.uni-giessen.de is derived from endogenous biosynthesis, which occurs mainly in the liver, and from intestinal absorption of carnitine from the diet (Vaz and Wanders, 2002). Tissues that are incapable of synthesizing carnitine, such as skeletal muscle or myocardium, are dependent on active carnitine uptake from the circulation. Active carnitine uptake is mainly mediated by the novel organic cation transporter 2 (OCTN2), a transporter that is sodiumdependent, high affinity, and broadly distributed in tissues (Tamai et al., 1998). The essential role of OCTN2 for carnitine homeostasis is shown by the fact that lack of OCTN2 due to a mutation in the OCTN2 gene leads to systemic carnitine deficiency (Lahjouji et al., 2001).

It was recently demonstrated that OCTN2 expression and carnitine concentration are elevated in the liver of high-yielding dairy cows during early lactation (Schlegel et al., 2012). It is known that the OCTN2 gene of many species, including cattle, is regulated by the transcriptional regulator peroxisome proliferator-activated receptor $\alpha$ (PPAR $\alpha$; Luo et al., 2014), that PPAR $\alpha$ activation stimulates OCTN2 expression and carnitine uptake in bovine kidney cells (Zhou et al., 2014), and that PPAR $\alpha$ is activated in the liver of dairy cattle during early lactation (Loor at al., 2005; Schlegel et al., 2012; Akbar et al., 2013). Based on this, it has been proposed that PPAR $\alpha$ activation represents the molecular basis for the above-mentioned increased OCTN2 expression and elevated carnitine concentration in the liver of lactating dairy cows (Schlegel et al., 2012).

However, apart from the established PPAR $\alpha-$ dependent regulation of the OCTN2 gene, it has been shown recently that pro-inflammatory cytokines, such as tumor necrosis factor $\alpha(\mathbf{T N F} \boldsymbol{\alpha})$, increase OCTN2 expression and sodium-dependent carnitine uptake in intestinal cells (Fujiya et al., 2011). Moreover, Fujiya et al. (2011) demonstrated that colonic OCTN2 expression is increased during active inflammation in the inflamed intestinal mucosa, where pro-inflammatory mediators are found at elevated concentrations. Interestingly, many high-yielding dairy cows show typical signs of hepatic and systemic inflammation, such as elevated concentrations of acute phase proteins and cytokines, including $\mathrm{TNF} \alpha$, during early lactation (Bionaz et al., 
2007; Vels et al., 2009). This is attributed to the exposure to diverse inflammatory challenges, such as TNF $\alpha$ and microbial components such as LPS, which arise from infectious diseases such as mastitis (Vels et al., 2009; Jørgensen et al., 2012), endometritis (Burke et al., 2010; Akbar et al., 2014), and rumen digestive disorders, such as subacute rumen acidosis (Plaizier et al., 2008; Zebeli and Metzler-Zebeli, 2012) and abomasal displacement (Guzelbektes et al., 2010), that frequently occur during parturition or at the onset of lactation.

In addition, it has been reported recently that nuclear factor- $\kappa \mathrm{B}(\mathbf{N F}-\boldsymbol{\kappa} \mathbf{B})$ is activated in different tissues, including the liver, of dairy cows during early lactation (Farney et al., 2013; Gessner et al., 2013). Nuclear factor- $\kappa \mathrm{B}$ is a key regulator of inflammation due to stimulating the transcription of genes involved in the inflammation process, including cytokines, chemokines, adhesion molecules, and acute phase proteins (Karin and Delhase, 2000). Many pro-inflammatory stimuli, such as TNFo and LPS, mediate their pro-inflamma-

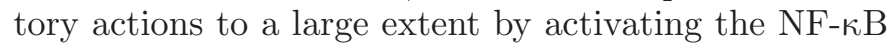
pathway (Baud and Karin, 2001; Vallabhapurapu and Karin, 2009). In view of this, it is possible that upregulation of OCTN2 gene expression and increase of carnitine uptake by TNF $\alpha$ is mediated by NF- $\kappa \mathrm{B}$, a mechanism that might also contribute to upregulation of OCNT2 in the liver of early-lactating dairy cows. Thus, in the present study, we tested the hypothesis that $\mathrm{TNF} \alpha$ stimulates OCTN2 gene expression and carnitine uptake via NF- $\kappa \mathrm{B}$ in a bovine cell line.

\section{MATERIALS AND METHODS}

\section{Cell Culture and Treatments}

The Madin-Darby bovine kidney (MDBK) cell line, a frequently used cell model to address mechanistic questions in bovine tissues (Bionaz et al., 2008), was obtained from Cell Lines Service (Eppelheim, Germany) and cultivated in HyClone Minimum Essential Medium/Earle's Balanced Salt Solution (MEM/ EBSS) supplemented with $10 \%$ fetal bovine serum (FBS) and $0.05 \mathrm{mg} / \mathrm{mL}$ gentamicin (all from Invitrogen, Karlsruhe, Germany) at $37^{\circ} \mathrm{C}$ in a humidified atmosphere of $95 \%$ air and $5 \% \mathrm{CO}_{2}$. For experiments, cells were seeded out into 6 -well plates at a density of $2.0 \times 10^{5}$ cells (for PCR and Western blotting experiments), 24-well plates at a density of $7 \times 10^{4}$ cells (for L-carnitine uptake studies), or 96-well plates at a density of $1.2 \times 10^{4}$ cells (for reporter gene assays) in HyClone MEM/EBSS complete medium. After reaching $80 \%$ confluence, MDBK cells were treated with dif- ferent concentrations of TNF $(0,1,5,10$ and $20 \mathrm{ng} /$ $\mathrm{mL}$; Sigma-Aldrich, Steinheim, Germany) dissolved in dimethyl sulfoxide (DMSO; Sigma-Aldrich) in MEM/ EBSS medium without FBS but with $5 \mathrm{mg} / \mathrm{L}$ bovine insulin (Sigma-Aldrich) for $24 \mathrm{~h}$. Cells treated with vehicle alone (DMSO) were used as control. Incubation medium of control cells contained the same vehicle concentration of $0.1 \%$ (vol/vol). For experiments using the NF- $\kappa$ B inhibitor, cells were co-treated with $5 \mathrm{ng} / \mathrm{mL}$ TNF $\alpha$ and $1 \mu M$ BAY 11-7085 (Merck, Bruchsal, Germany). All experiments were performed 3 times from a different cell passage number $(=3$ independent experiments). An independent experiment was defined as an experiment performed with cells of a specific passage number and included seeding, treatment, and analysis.

\section{Quantitative Real-Time PCR}

Total RNA was isolated from the MDBK cell layer after a washing step with PBS using Trizol reagent (Invitrogen) according to the manufacturer's instructions. The RNA from cells was extracted within $3 \mathrm{~d}$ after the experiment. Isolated RNA was stored at $-80^{\circ} \mathrm{C}$ until use. Concentrations and purity of isolated RNA were determined using an Infinite $200 \mathrm{M}$ microplate reader and a NanoQuant Plate (both from Tecan, Mannedorf, Switzerland). The integrity of RNA was assessed by $1 \%$ agarose gel electrophoresis, and RNA was considered to be suitable for use only if intact bands corresponding to $18 \mathrm{~S}$ and $28 \mathrm{~S}$ rRNA subunits were visible. First-strand cDNA was synthesized from $1.2 \mu \mathrm{g}$ of total RNA using 100 pmol of dT18 primer (Eurofins MWG Operon, Ebersberg, Germany), $1.25 \mu \mathrm{L}$ of $10 \mathrm{mM}$ dNTP mix (GeneCraft, Lüdinghausen, Germany), $5 \mu \mathrm{L}$ of buffer (Fermentas, St. Leon-Rot, Germany), and 60 units of M-MuLV Reverse Transcriptase (MBI Fermentas, St. Leon-Rot, Germany) at $42^{\circ} \mathrm{C}$ for $60 \mathrm{~min}$ and a subsequent inactivating step at $70^{\circ} \mathrm{C}$ for $10 \mathrm{~min}$ in Biometra Thermal Cycler (Whatman Biometra, Göttingen, Germany). Finally, cDNA was preserved in aliquots at $-20^{\circ} \mathrm{C}$. Quantitative real-time (q)PCR was performed using $2 \mu \mathrm{L}$ of cDNA combined with $18 \mu \mathrm{L}$ of a mixture composed of $10 \mu \mathrm{L}$ of KAPA SYBR FAST qPCR Universal Mastermix (Peqlab, Erlangen, Germany), $0.4 \mu \mathrm{L}$ each of forward and reverse primers $(10 \mu M)$, and 7.2 $\mu \mathrm{L}$ of DNase- and RNase-free water in 0.1-mL tubes (Ltf Labortechnik, Wasserburg, Germany). Primer pairs were designed using Primer3 software (Whitehead Institute for Biomedical Research, Cambridge, MA) to have melting temperatures of about $60^{\circ} \mathrm{C}$, and, if possible, both primers of a primer pair were designed to be located in different exons. Characteristics of primer pairs and qPCR performance data are listed in Table 
Table 1. Primer characteristics used for quantitative PCR



${ }^{1} A C T B=\beta$-actin; $A T P 5 B=$ ATP synthase, $\mathrm{H}^{+}$transporting, mitochondrial $\mathrm{F} 1$ complex, $\beta$ polypeptide; OCTN2 = solute carrier family 22 (organic cation/carnitine transporter), member $5 ; P P I A=$ peptidylprolylisomerase A; RPS 9 = ribosomal protein $\mathrm{S} 9 ; S D H A=$ succinate dehydrogenase complex, subunit A.

1. Quantitative PCR runs were performed with a Rotorgene 2000 system (Corbett Research, Mortlake, Australia) using the following protocol: $3 \mathrm{~min}$ at $95^{\circ} \mathrm{C}$, followed by 40 cycles of a 2 -step PCR consisting of 5 $\mathrm{s}$ at $95^{\circ} \mathrm{C}$ (denaturation) and $20 \mathrm{~s}$ at $60^{\circ} \mathrm{C}$ (annealing and extension). Subsequently, melting curve analysis was performed from $50^{\circ} \mathrm{C}$ to $95^{\circ} \mathrm{C}$ to verify the presence of a single PCR product. Calculation of gene expression data and normalization by GeNorm normalization factor was carried out as described recently in detail (Keller et al., 2012). The normalization factor was calculated as the geometric mean of expression data of the 3 most stable out of 5 tested [ $\beta$-actin $(A C T B)$, ATP synthase, $\mathrm{H}^{+}$transporting, mitochondrial $\mathrm{F} 1$ complex, $\beta$ polypeptide $(A T P 5 B)$, peptidylprolylisomerase A $(P P I A)$, ribosomal protein S9 (RPS9), succinate dehydrogenase complex, subunit A $(S D H A)]$ potential reference genes. Normalized gene expression level of treated cells ( $\mathrm{TNF} \alpha, \mathrm{TNF} \alpha+\mathrm{BAY}$ 11-7085) is presented relative to that of control cells (DMSO), which was set to 1.0. In each independent experiment, all treatments (dose-response relationship: 0, 1, 5, 10, $20 \mathrm{ng}$ of TNF $\alpha$ / $\mathrm{mL}$; other experiments: DMSO, TNF $\alpha, \mathrm{TNF} \alpha+\mathrm{BAY}$ 11-7085) were represented once (1 well per treatment) in each 6-well plate. Three identical 6-well plates were included in each independent experiment. Within one independent experiment, all wells from the three 6 -well plates were analyzed and a single mean representing the experimental unit was calculated for each treatment from the three 6 -well plates. Three independent experiments were run; thus, the total number of experimental units was 3 .

\section{Transient Transfection and Reporter Gene Assay}

Madin-Darby bovine kidney cells with a confluency of $65 \%$ were transiently transfected with $50 \mathrm{ng}$ of NF$\kappa B-l u c i f e r a s e$ reporter plasmid (Takara Bio Europe/ Clontech, Saint-Germain-en-Laye, Germany), a plasmid containing an NF- $\kappa \mathrm{B}$ response element in front of the firefly-luciferase reporter gene, and $5 \mathrm{ng}$ of pGL4.74 Renilla-luciferase plasmid (Promega, Mannheim, Germany), a control vector used for normalization, using FuGENE 6 transfection reagent (Roche Diagnostics, Mannheim, Germany) for $8 \mathrm{~h}$. Subsequently, the MDBK cells were treated without or with $5 \mathrm{ng} / \mathrm{mL}$ of $\mathrm{TNF} \alpha$ for $24 \mathrm{~h}$ as described above. Following incubation, cells were washed with PBS and lysed with passive lysis buffer (Promega). Luciferase activities were measured using Beetle-Juice and Renilla-Juice Kits from PJK (Kleinblittersdorf, Germany) using a Mithras LB940 luminometer (Berthold Technologies, Bad Wildbad, Germany). Data were normalized for transfection efficiency by dividing firefly-luciferase activity by that of Renilla-luciferase activity. Normalized luciferase activity of $\mathrm{TNF} \alpha$-treated cells is shown relative to that of control cells (DMSO), which was set to 1.0. In each independent experiment, all treatments (DMSO, TNFa) were represented in 3 wells (3 technical replicates per treatment) in each 96-well plate. Within one independent experiment, all technical replicates were analyzed and a single mean representing the experimental unit was calculated for each treatment. Three independent experiments were run; thus, the total number of experimental units was 3 . 


\section{Immunoblotting}

The MDBK cells were washed once with PBS and then lysed with radioimmunoprecipitation assay (RIPA) lysis buffer $(50 \mathrm{~m} M$ Tris, $\mathrm{pH} 7.5 ; 150 \mathrm{~m} M \mathrm{NaCl}, 1$ $\mathrm{m} M$ EDTA, $1 \%$ Triton X-100, $0.1 \%$ SDS, $1 \%$ sodium deoxycholate) containing protease inhibitors (SigmaAldrich). Determination of protein concentration of cell lysates, protein separation by SDS-PAGE, protein transfer to nitrocellulose membranes, and immunodetection of OCTN2 and $\beta$-actin as reference protein were carried out as described recently (Zhou et al., 2014). For calculation of protein expression data, the band intensity of OCTN2 was normalized to that of $\beta$-actin and normalized protein expression level of treated cells (TNFo, $\mathrm{TNF} \alpha+\mathrm{BAY} 11-7085)$ is presented relative to that of control cells (DMSO), which was set to 1.0. In each independent experiment, all treatments (DMSO, $\mathrm{TNF} \alpha, \mathrm{TNF} \alpha+\mathrm{BAY}$ 11-7085) were represented once (one well per treatment) in each 6 -well plate. Three identical 6-well plates were included in each independent experiment. Within one independent experiment, all wells from the three 6 -well plates were analyzed and a single mean representing the experimental unit was calculated for each treatment from the three 6-well plates. Three independent experiments were run; thus, the total number of experimental units was 3 .

\section{Carnitine Uptake}

The MDBK cells were washed 2 times with $1.5 \mathrm{~mL}$ of Hanks' balanced salts solution (HBSS, Biochrom AG, Berlin, Germany) with $5 \mathrm{~m} M$ HEPES (pH 7.4; Sigma, Steinheim, Germany), and then incubated in a buffer containing $10 \mathrm{n} M$ methyl-L- $\left[{ }^{3} \mathrm{H}\right]$-carnitine $(80 \mathrm{mCi} /$ mmol; American Radiolabeled Chemicals, St. Louis, $\mathrm{MO}), 125 \mathrm{~m} M \mathrm{NaCl}, 4.8 \mathrm{~m} M \mathrm{KCl}, 5.6 \mathrm{~m} M$ D-glucose, $1.2 \mathrm{~m} M \mathrm{CaCl}_{2}, 1.2 \mathrm{~m} M \mathrm{KH}_{2} \mathrm{PO}_{4}, 1.2 \mathrm{mM} \mathrm{MgSO}_{4}$, and $5 \mathrm{~m} M$ HEPES at $37^{\circ} \mathrm{C}$ for $30 \mathrm{~min}$ according to the method of Glube et al. (2007). Following incubation, the buffer was aspirated and cells were washed 2 times with ice-cold buffered HBSS and thereafter dissolved with $0.5 \mathrm{~mL}$ of $1 \mathrm{M} \mathrm{NaOH}$ for $1 \mathrm{~h}$ with shaking at room temperature. Radioactivity in cell lysates was determined by scintillation counting (Liquid Scintillation Analyzer Tri-Carb 2900TR, Perkin Elmer, Rodgau, Germany) and related to protein content of cell lysates as determined by the bicinchoninic acid protein assay with BSA as standard. Carnitine uptake was expressed as the amount of $\mathrm{L}-\left[{ }^{3} \mathrm{H}\right]$-carnitine taken up per milligram of cell protein within $30 \mathrm{~min}$. In each independent experiment, all treatments (DMSO, TNF $\alpha, \mathrm{TNF} \alpha+$ BAY 11-7085) were represented in 3 wells (3 technical replicates per treatment) in each 24 -well plate. Within one independent experiment, all technical replicates were analyzed and a single mean representing the experimental unit was calculated for each treatment. Three independent experiments were run; thus, the total number of experimental units was 3 .

\section{Statistics}

All data represent means and standard deviations (SD), which were calculated from the means for the same treatments of 3 independent experiments. Statistical analysis was performed using the Minitab statistical software (release 13.0; Minitab Inc., State College, PA). Data of each independent experiment were analyzed for normality of distribution (Anderson-Darling test). Because all data showed a normal distribution, one-way ANOVA was applied to evaluate the effect of treatment. Effects were considered significant if $P<$ 0.05. If one-way ANOVA revealed significant effects, a post hoc comparison (Fisher's multiple comparison) was applied.

\section{RESULTS}

To investigate the suitability of TNF $\alpha$ as an activator of NF- $\kappa \mathrm{B}$ in MDBK cells, the dose-response relationship between $\mathrm{TNF} \alpha(0,1,5,10,20 \mathrm{ng} / \mathrm{mL})$ and the mRNA concentration of the known NF- $\kappa \mathrm{B}$ target gene IL6 in MDBK cells was studied first. As shown in Figure 1A, treatment of MDBK cells with TNFo dose-dependently increased the IL6 mRNA concentration compared with vehicle control treatment. Considering that $5 \mathrm{ng} / \mathrm{mL}$ of $\mathrm{TNF} \alpha$ caused a strong ( 15 -fold $)$ increase in the $I L 6$ mRNA concentration and higher TNF $\alpha$ concentrations (10 and $20 \mathrm{ng} / \mathrm{mL}$ ) caused only a modest additional increase in the IL6 mRNA concentration (Figure 1A), $5 \mathrm{ng} / \mathrm{mL}$ TNF $\alpha$ was used for NF- $\mathrm{BB}$ activation in subsequent experiments.

To demonstrate direct activation of NF- $\kappa \mathrm{B}$ by $\mathrm{TNF} \alpha$ in MDBK cells, we next investigated the effect of $\mathrm{TNF} \alpha$ on activation of a luciferase reporter plasmid containing the consensus NF- $\kappa \mathrm{B}$ response element in MDBK cells transiently transfected with this plasmid. This experiment revealed that the NF- $\kappa \mathrm{B}$-driven luciferase reporter was activated about 3 -fold by TNFo in MDBK cells, indicating that $\mathrm{TNF} \alpha$ directly activates $\mathrm{NF}-\kappa \mathrm{B}$ (Figure 1B).

To further explore whether the stimulatory effect of TNFo on IL 6 mRNA concentration in MDBK cells is mediated via NF- $\kappa B$, we studied the effect of blocking $\mathrm{NF}-\kappa \mathrm{B}$ activation by the NF- $\kappa \mathrm{B}$ inhibitor BAY 11$7085(1 \mu M)$. BAY 11-7085 inhibits NF- $\kappa \mathrm{B}$ through irreversible inhibition of $\mathrm{I} \kappa \mathrm{B} \alpha$ phosphorylation, thereby preventing activation of NF- $\kappa \mathrm{B}$ by $\mathrm{TNF} \alpha$ and other 
A

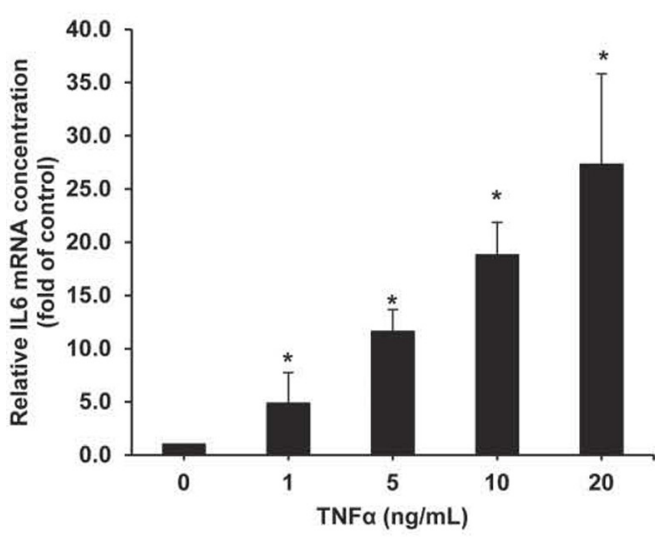

B
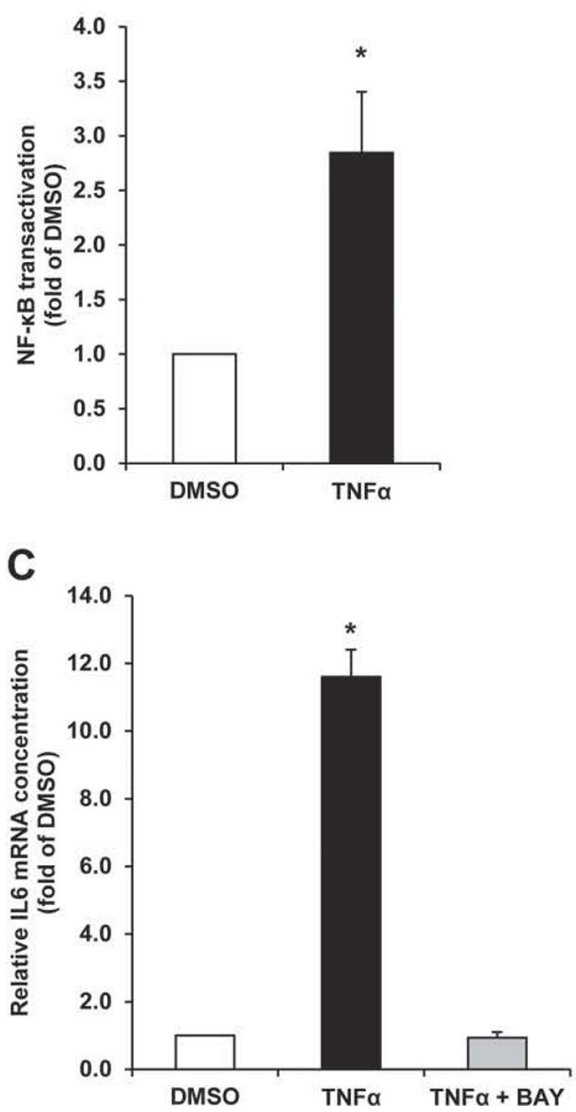

Figure 1. (A) Effect of 24-h treatment with different concentrations of tumor necrosis factor $\alpha$ (TNFo; $0,1,5,10,20 \mathrm{ng} / \mathrm{mL})$ on relative IL6 mRNA concentration in Madin-Darby bovine kidney (MDBK) cells. Cells treated with vehicle (dimethyl sulfoxide, DMSO) only (0 ng of $\mathrm{TNF} \alpha / \mathrm{mL}$ ) served as control. (B) Effect of 24 -h treatment with $\mathrm{TNF} \alpha(5 \mathrm{ng} / \mathrm{mL})$ compared with treatment with vehicle only (DMSO) on nuclear factor- $\kappa \mathrm{B}(\mathrm{NF}-\kappa \mathrm{B})$ transactivation in MDBK cells. (C) Effect of 24-h treatment with either TNFa $(5 \mathrm{ng} / \mathrm{mL})$ alone or TNFa $(5 \mathrm{ng} / \mathrm{mL})$ and NF- $\mathrm{BB}$ inhibitor BAY 11-7085 (BAY; $1 \mu M$ ) compared with treatment with vehicle only (DMSO) on relative $I L 6$ mRNA concentration in MDBK cells. In all panels, bars represent means $\pm \mathrm{SD}$ of 3 independent experiments $(\mathrm{n}=3)$ and are expressed as fold of DMSO-treated control. *Different from DMSO-treated control, $P<0.05$. cytokines, as well as LPS. As shown in Figure 1C, the stimulatory effect of TNFa on IL6 mRNA concentration was completely abolished by BAY 11-7085, suggesting that $\mathrm{TNF} \alpha$ stimulates $I L 6$ gene transcription via $\mathrm{NF}-\kappa \mathrm{B}$ in MDBK cells.

Based on the finding that NF- $\kappa \mathrm{B}$ is activated by TNFo in MDBK cells, we next studied the effect of NF$\kappa \mathrm{B}$ activation by TNFo on gene expression of OCTN2 in MDBK cells. This experiment demonstrated that treatment of cells with $\mathrm{TNF} \alpha$ increased the mRNA and protein concentration of OCTN2 in MDBK cells by 1.7and 2.5-fold, respectively (Figure $2 \mathrm{~A}$ and $2 \mathrm{~B}$ ), indicating that OCTN2 gene expression in bovine MDBK cells is regulated by the pro-inflammatory cytokine $\mathrm{TNF} \alpha$. To explore a mechanistic role of $\mathrm{NF}-\kappa \mathrm{B}$ for this effect of TNFo, we investigated the effect of TNF $\alpha$ on OCTN2 gene expression during blockage of NF- $\mathrm{KB}$ by BAY 11-7085. This experiment revealed that BAY 11-7085 completely abolished the stimulatory effect of $\mathrm{TNF} \alpha-$ induced NF- $\kappa \mathrm{B}$ activation on OCTN2 mRNA and protein concentrations (Figure $2 \mathrm{C}$ and $2 \mathrm{D}$ ), suggesting that OCTN2 gene expression in MDBK cells is regulated by NF- $\kappa \mathrm{B}$. In contrast to the mRNA expression of OCTN2, no mRNA expression of the $\gamma$-butyrobetaine dioxygenase ( $B B O X 1)$ gene, which encodes the enzyme catalyzing the final step of carnitine biosynthesis, could be detected in MDBK cells by means of qPCR and conventional PCR (data not shown).

To finally investigate whether the upregulation of OCTN2 by TNF $\alpha$ has an influence on carnitine uptake, which is largely mediated by OCTN2 under physiological conditions, we studied the uptake of methyl-L- $\left[{ }^{3} \mathrm{H}\right]-$ carnitine into MDBK monolayer. As illustrated in Figure 3 , the uptake of L-carnitine into MDBK cells increased about $35 \%$ in cells treated with TNFo compared with cells treated with vehicle alone $(P<0.05)$. To study the NF- $\kappa \mathrm{B}$ dependence of the TNF $\alpha$-stimulated increase of L-carnitine uptake, we also studied the effect of $\mathrm{TNF} \alpha$ on L-carnitine uptake by MDBK cells during blockage of NF- $\kappa$ B by BAY 11-7085. As shown in Figure 3, the effect of TNFo on L-carnitine uptake was completely blocked by BAY 11-7085, suggesting that the effect of $\mathrm{TNF} \alpha$ on L-carnitine uptake is mediated by NF- $\kappa \mathrm{B}$.

\section{DISCUSSION}

The main finding of the present study is that the pro-inflammatory cytokine $\mathrm{TNF} \alpha$ stimulates gene expression of OCTN2 and carnitine uptake in the bovine MDBK cell line, and co-treatment of cells with an $\mathrm{NF}-\kappa \mathrm{B}$ inhibitor blocks the $\mathrm{TNF} \alpha$-induced stimulation of OCTN2 gene expression and carnitine uptake in this cell line. The OCTN2 protein is essential for carnitine homeostasis through its important role in 
A
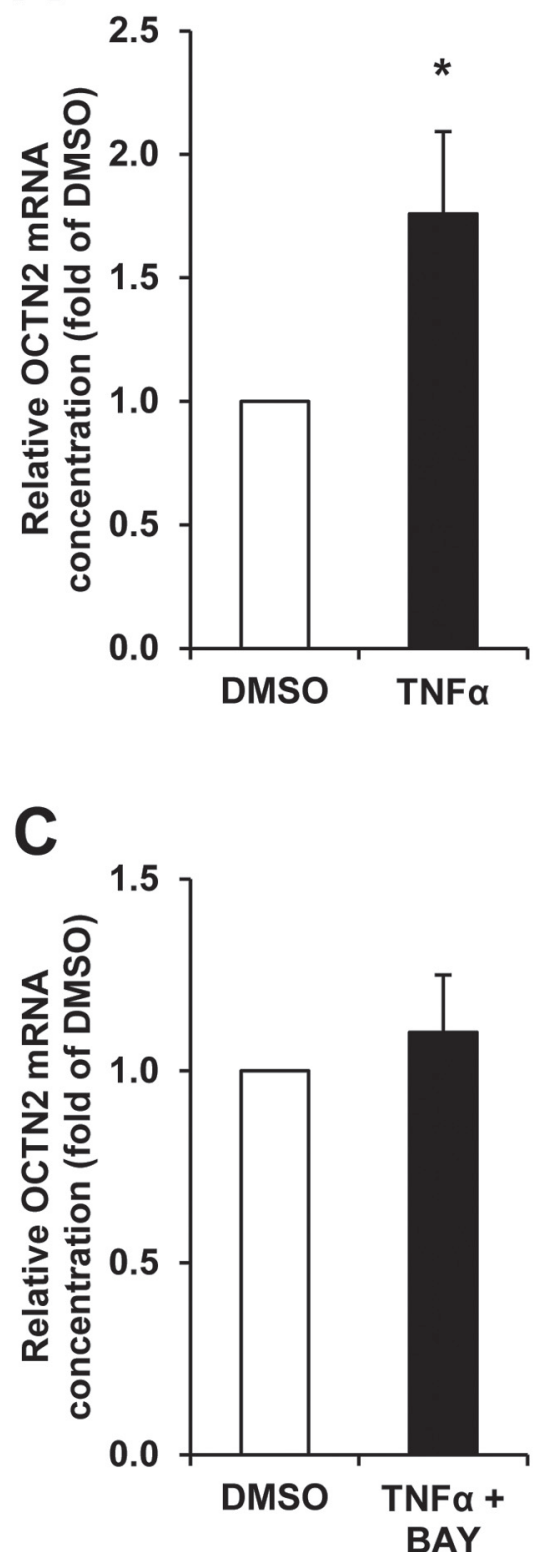

B
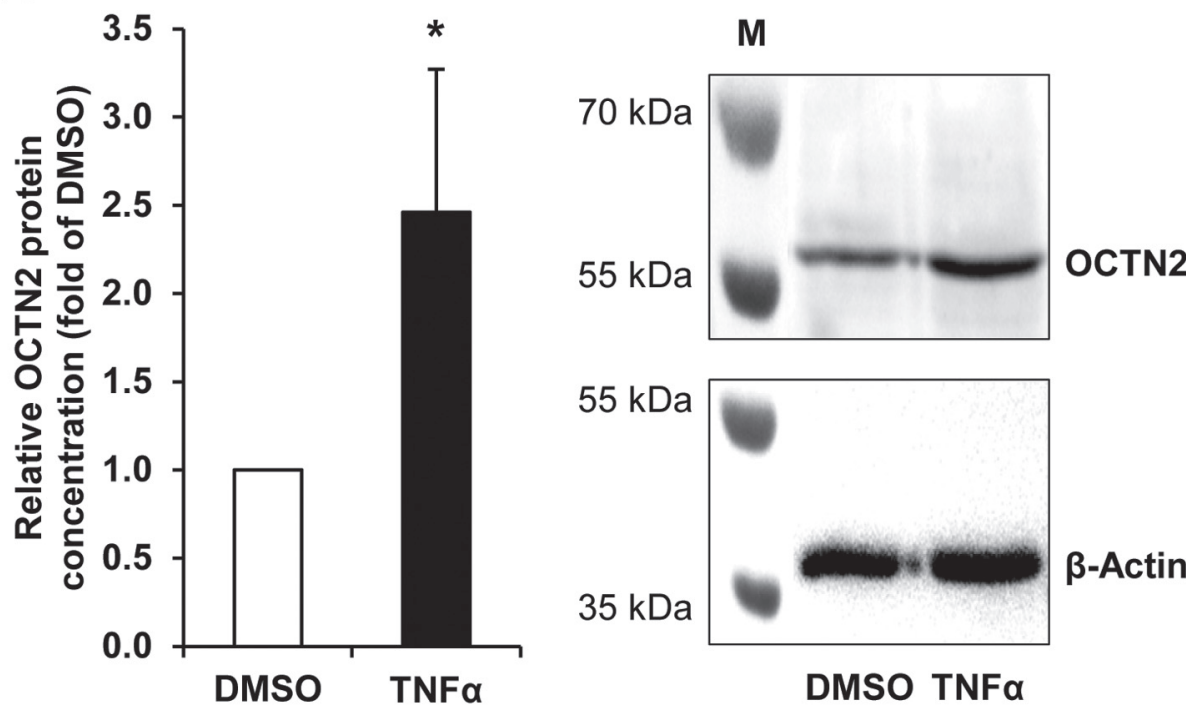

D

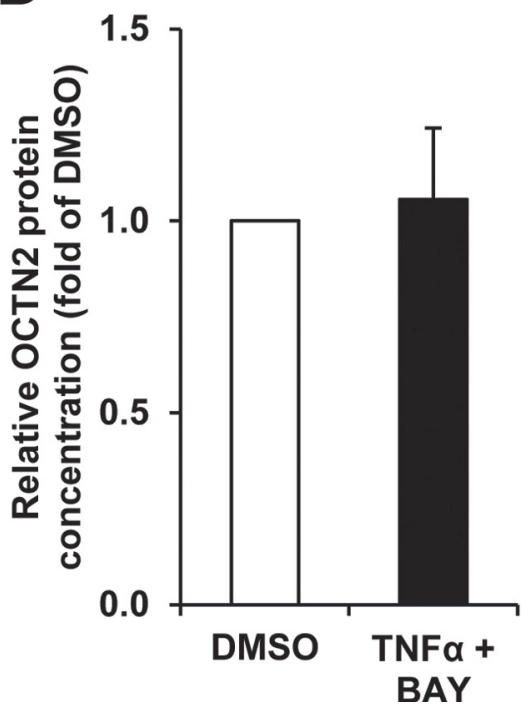

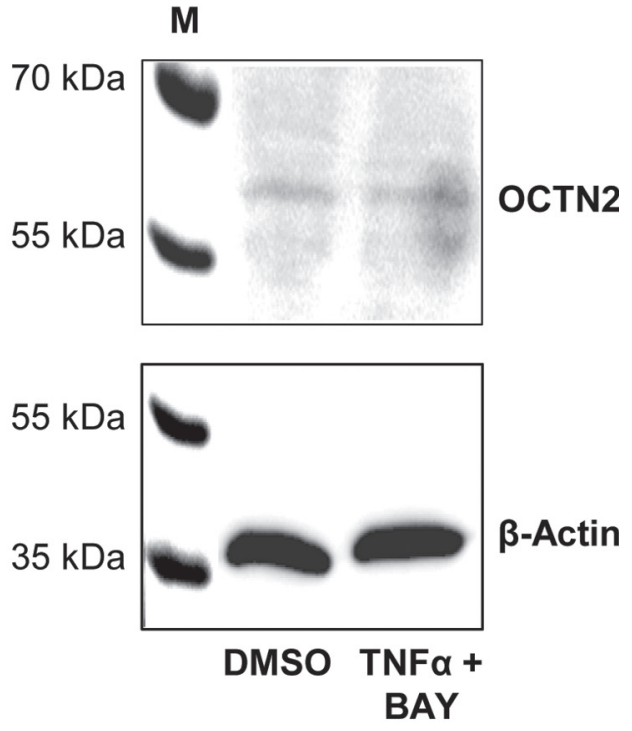

Figure 2. Effect of $24 \mathrm{~h}$ treatment with either tumor necrosis factor $\alpha$ (TNF $\alpha 5 \mathrm{ng} / \mathrm{mL}$ ) alone (panels $\mathrm{A}$ and $\mathrm{B})$ or $\mathrm{TNF} \alpha(5 \mathrm{ng} / \mathrm{mL})$ and nuclear factor- $\kappa \mathrm{B}$ inhibitor BAY 11-7085 (BAY; $1 \mu M$ ) (panels C and D) compared with treatment with vehicle only (dimethyl sulfoxide, DMSO) on relative mRNA (A and C) and protein concentrations (B and D) of OCTN2 [solute carrier family 22 (organic cation/carnitine transporter), member 5] in Madin-Darby bovine kidney (MDBK) cells. In all panels, bars represent means \pm SD of 3 independent experiments $(\mathrm{n}=3)$ and are expressed as fold of DMSO-treated control. In panels B and D, immunoblots specific to OCTN2 and $\beta$-actin (as internal control) including the size marker $(\mathrm{M})$ are shown for one independent experiment; immunoblots for the other experiments revealed similar results. ${ }^{*}$ Different from DMSO-treated control, $P<0.05$.

carnitine distribution between tissues and the tubular carnitine reabsorption process in the kidney, which is evidenced by the fact that mutations in the OCTN2 gene lead to systemic carnitine deficiency, at least in humans (Lahjouji et al., 2001). Given this important role of OCTN2 for carnitine uptake, it is likely that the $\mathrm{TNF} \alpha$-stimulated carnitine uptake observed in this study was due to upregulation of OCTN2. Considering that inhibition of NF- $\kappa \mathrm{B}$, which is known to be activated by TNFo and other pro-inflammatory cytokines (Baud and Karin, 2001; Vallabhapurapu and Karin, 2009), completely abolished the effect of $\mathrm{TNF} \alpha$ on $O C T N 2$ expression and carnitine uptake, it is likely that OCTN2 is regulated by the NF- $\mathrm{B}$ pathway, at 


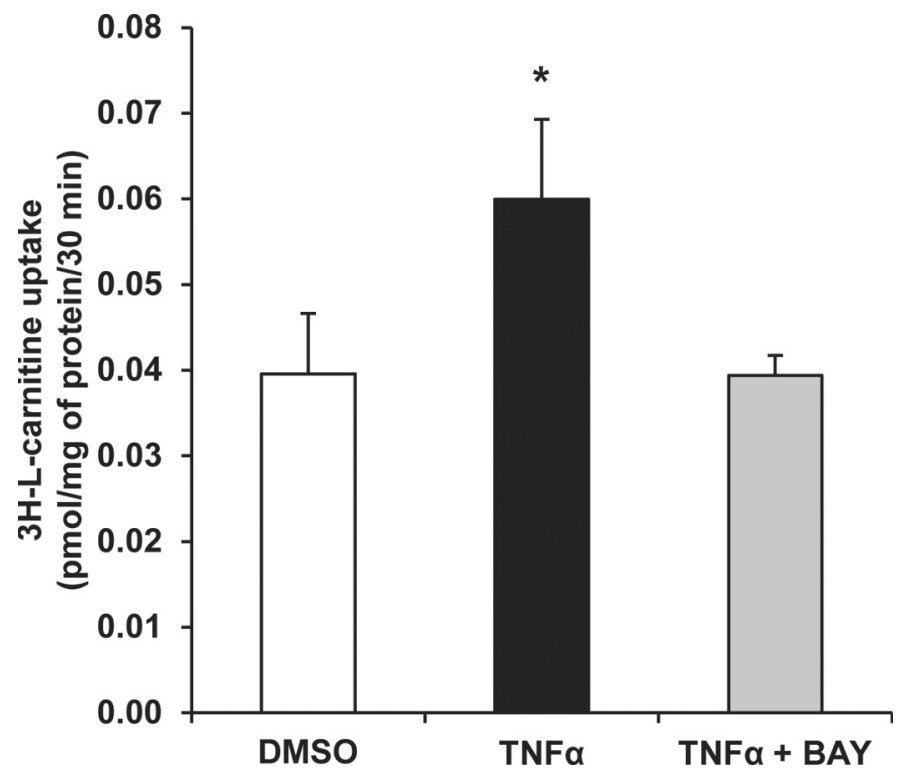

Figure 3. Effect of 24-h treatment with either tumor necrosis factor $\alpha(\mathrm{TNF} \alpha ; 5 \mathrm{ng} / \mathrm{mL})$ alone or TNF $\alpha(5 \mathrm{ng} / \mathrm{mL})$ and nuclear factor$\kappa \mathrm{B}$ inhibitor BAY 11-7085 (BAY; $1 \mu M$ ) compared with treatment with vehicle only (dimethyl sulfoxide, DMSO) on uptake of L- $\left[{ }^{3} \mathrm{H}\right]$ carnitine $(10 \mathrm{n} M$, specific radioactivity $80 \mathrm{Ci} / \mathrm{mmol}$ ) by Madin-Darby bovine kidney (MDBK) cells; uptake of L- $\left[{ }^{3} \mathrm{H}\right]$-carnitine was studied over 30 min. Bars represent means \pm SD of 3 independent experiments $(\mathrm{n}=3)$. ${ }^{*}$ Different from DMSO-treated control, $P<0.05$.

least indirectly. In line with a regulatory role of proinflammatory cytokines for OCTN2 expression, it has been demonstrated recently that pro-inflammatory cytokines, such as $\mathrm{TNF} \alpha$ and interferon- $\gamma$, increase OCTN2 expression and sodium-dependent carnitine uptake, which is characteristic for OCTN2-mediated carnitine transport, in human and mouse intestinal cells (Fujiya et al., 2011). Those authors also demonstrated that colonic OCTN2 expression is increased during active inflammation in the inflamed intestinal mucosa of mice, where pro-inflammatory mediators are generated and present at elevated concentrations. Fujiya et al. (2011) proposed that the upregulation of OCTN2 in the inflamed mouse intestine plays a role in mediating host response to injury and stress. This assumption is based on the knowledge that OCTN2 also mediates the uptake of small bacterial peptides in human and mouse intestinal cells, resulting in the induction of cytoprotective heat-shock proteins and activation of key signaling pathways $[$ Akt/PKB (protein kinase B), MAPK (mitogen-activated protein kinase)]. These events are supposed to confer protection of intestinal epithelial cells to the injurious effects of reactive oxygen species and contribute to restoration of intestinal homeostasis (Fujiya et al., 2007). Although speculative, upregulation of OCTN2 might be also a means to increase ATP synthesis from fatty acid oxidation and energy status in the stressed cell due to the role of carnitine as a shuttling molecule for the import of long-chain fatty acids into the mitochondrial matrix. It is widely known that many high-yielding dairy cows show typical signs of systemic inflammation, such as elevated concentrations of acute phase proteins, during early lactation (Bionaz et al., 2007; Vels et al., 2009). This is attributed to the exposure to diverse inflammatory challenges, such as pro-inflammatory cytokines including $\mathrm{TNF} \alpha$, reactive oxygen species, and microbial components, which arise from infectious diseases, such as mastitis and endometritis, but also subacute rumen acidosis and abomasal displacement that occur frequently during parturition and onset of lactation. Moreover, it has been reported that signaling pathways, which are involved critically in stress and inflammatory response, such as the NF- $\kappa \mathrm{B}$ (Gessner et al., 2013), the Nrf2 (Moyes et al., 2010; Gessner et al., 2013), and the ER stress-induced unfolded protein response (UPR) pathway (Invernizzi et al., 2012; Gessner et al., 2014) are activated in different tissues of dairy cows during early lactation. Thus, proinflammatory cytokines might play a role in upregulating OCTN2 and increasing carnitine uptake in tissues of dairy cows during early lactation, and the upregulation of OCTN2 might be involved in the restoration of tissue homeostasis under conditions of inflammationassociated stress.

To the best of our knowledge, expression of OCTN2 in rumen epithelium has not been described yet, but considering the ubiquitous expression of OCTN2 in tissues of other species (Alnouti et al., 2006), this is not unlikely. It remains to be seen whether OCTN2 mediates protective functions in the rumen epithelium of cattle, as has been shown in human and mouse intestinal cells (Fujiya et al., 2007, 2011). This question is relevant considering the critical role of an intact barrier function of the rumen epithelium for preventing inflammation and other health-related problems in ruminants (Zebeli and Metzler-Zebeli, 2012). In goats, feeding a high energy diet and the subsequent rumen acidosis caused a downregulation of several protective proteins in the rumen epithelium (Hollmann et al., 2013). This might impair the cellular defense system of the rumen epithelium, thereby increasing the risk for local inflammation and allowing infectious agents to enter the systemic circulation.

We have recently shown that OCTN2 expression and carnitine uptake in bovine MDBK cells are also regulated by PPAR $\alpha$ (Zhou et al., 2014), and at least the murine, porcine, and bovine OCTN2 genes have been convincingly identified as direct PPAR $\alpha$ target genes (Wen et al., 2010; Luo et al., 2014). Moreover, it has been demonstrated that PPAR $\alpha$ is activated in the liver of dairy cows during early lactation (Loor 
at al., 2005; Schlegel et al., 2012; Akbar et al., 2013), providing a plausible explanation for the recent finding that OCTN2 in the liver is strongly upregulated during early lactation in high-producing dairy cows (Schlegel et al., 2012). Nonetheless, the present findings from cell culture experiments suggest that activation of NF- $\kappa \mathrm{B}$ might also contribute to upregulation of OCTN2 in the liver of cows during lactation. Despite data showing negative crosstalk between PPAR $\alpha$ activation and NF- $\kappa B$ signaling (Delerive et al., 1999), evidence shows that both pathways are activated in different tissues, including the liver, of dairy cows during early lactation (Loor at al., 2005; Farney et al., 2013; Gessner et al., 2013).

The present study has one limitation: Due to the lack of a bovine hepatocyte cell line, a bovine kidney cell line (MDBK) was used for the experiments. Nevertheless, we are confident that MDBK cells, which are widely used to investigate mechanistic questions in bovine tissues (Bionaz et al., 2008; Thering et al., 2009), are suitable for addressing this specific question, because OCTN2 expression is regulated similarly, at least by PPAR $\alpha$, in different cell types including hepatocytes and kidney cells (Luci et al., 2006; Zhou et al., 2014). Thus, we expect the same mechanism of regulation by TNFo in liver cells. It is well known that carnitine synthesis occurs in both liver and kidney in several species (Vaz and Wanders, 2002). To the best of our knowledge, it remains to be shown whether the bovine kidney is able to synthesize carnitine. Interestingly, our experiments with MDBK cells revealed that this cell line does not express $B B O X 1 \mathrm{mRNA}$, which is essential for carnitine homeostasis because it catalyzes the final step of carnitine biosynthesis. This indicates that at least this bovine cell line lacks the ability to synthesize carnitine. It has been demonstrated that cellular carnitine uptake and carnitine synthesis can be stimulated in parallel (Luci et al., 2006) and no study has yet demonstrated that carnitine synthesis reduces carnitine uptake or vice versa. Thus, these findings indicate that MDBK cells are a suitable cell model to study regulation of OCTN2 expression by $\mathrm{TNF} \alpha$ and that the lack of carnitine synthesis does not undermine the present observations.

\section{CONCLUSIONS}

The present study shows that expression of the carnitine transporter OCTN2 and OCTN2-mediated carnitine uptake are stimulated by the pro-inflammatory cytokine $\mathrm{TNF} \alpha$ in bovine MDBK cells, an effect that is blocked by inhibition of NF- $\kappa \mathrm{B}$. This suggests that the bovine OCTN2 gene is regulated by NF- $\kappa \mathrm{B}$. Future studies must clarify whether regulation of the OCTN2 gene by NF- $\mathrm{KB}$ is mediated directly through binding to a NF- $\kappa \mathrm{B}$ response element in the regulatory region of the OCTN2 gene. In addition, studies are required to show the in vivo relevance of this regulatory mechanism in cattle.

\section{ACKNOWLEDGMENTS}

Xiaodan Zhou was supported by a scholarship from the China Scholarship Council (CSC, Beijing, China).

\section{REFERENCES}

Akbar, H., F. C. Cardoso, S. Meier, C. Burke, S. McDougall, M. Mitchell, C. Walker, S. L. Rodriguez-Zas, R. E. Everts, H. A. Lewin, J. R. Roche, and J. J. Loor. 2014. Postpartal subclinical endometritis alters transcriptome profiles in liver and adipose tissue of dairy cows. Bioinform. Biol. Insights 8:45-63.

Akbar, H., E. Schmitt, M. A. Ballou, M. N. Corrêa, E. J. Depeters, and J. J. Loor. 2013. Dietary lipid during late-pregnancy and early-lactation to manipulate metabolic and inflammatory gene network expression in dairy cattle liver with a focus on PPARs. Gene Regul. Syst. Bio. 7:103-123.

Alnouti, Y., J. S. Petrick, and C. D. Klaassen. 2006. Tissue distribution and ontogeny of organic cation transporters in mice. Drug Metab. Dispos. 34:477-482.

Baud, V., and M. Karin. 2001. Signal transduction by tumor necrosis factor and its relatives. Trends Cell Biol. 11:372-377.

Bionaz, M., C. R. Baumrucker, E. Shirk, J. P. VandenHeuvel, E. Block, and G. A. Varga. 2008. Characterization of Madin-Darby bovine kidney cell line for peroxisome proliferator-activated receptors: temporal response and sensitivity to fatty acids. J. Dairy Sci. 91:2808-2813.

Bionaz, M., E. Trevisi, L. Calamari, F. Librandi, A. Ferrari, and G. Bertoni. 2007. Plasma paraoxonase, health, inflammatory conditions, and liver function in transition dairy cows. J. Dairy Sci. 90:1740-1750.

Burke, C. R., S. Meier, S. McDougall, C. Compton, M. Mitchell, and J. R. Roche. 2010. Relationships between endometritis and metabolic state during the transition period in pasture-grazed dairy cows. J. Dairy Sci. 93:5363-5373.

Delerive, P., K. De Bosscher, S. Besnard, W. Vanden Berghe, J. M. Peters, F. J. Gonzalez, J. C. Fruchart, A. Tedgui, G. Haegeman, and B. Staels. 1999. Peroxisome proliferator-activated receptor $\alpha$ negatively regulates the vascular inflammatory gene response by negative cross-talk with transcription factors NF- $\mathrm{KB}$ and AP-1. J. Biol. Chem. 274:32048-32054.

Farney, J.K., L. K. Mamedova, J. F. Coetzee, B. KuKanich, L. M. Sordillo, S. K. Stoakes, J. E. Minton, L. C. Hollis, and B. J. Bradford. 2013. Anti-inflammatory salicylate treatment alters the metabolic adaptations to lactation in dairy cattle. Am. J. Physiol. Regul. Integr. Comp. Physiol. 305:R110-R117.

Fujiya, M., Y. Inaba, M. W. Musch, S. Hu, Y. Kohgo, and E. B. Chang. 2011. Cytokine regulation of OCTN2 expression and activity in small and large intestine. Inflamm. Bowel Dis. 17:907-916.

Fujiya, M., M. W. Musch, Y. Nakagawa, S. Hu, J. Alverdy, Y. Kohgo, O. Schneewind, B. Jabri, and E. B. Chang. 2007. The Bacillus subtilis quorum-sensing molecule CSF contributes to intestinal homeostasis via OCTN2, a host cell membrane transporter. Cell Host Microbe 1:299-308.

Gessner, D. K., G. Schlegel, J. Keller, F. J. Schwarz, R. Ringseis, and K. Eder. 2013. Expression of target genes of nuclear factor E2related factor 2 in the liver of dairy cows in the transition period and at different stages of lactation. J. Dairy Sci. 96:1038-1043.

Gessner, D. K., G. Schlegel, R. Ringseis, F. J. Schwarz, and K. Eder. 2014. Up-regulation of endoplasmic reticulum stress induced genes 
of the unfolded protein response in the liver of periparturient dairy cows. BMC Vet. Res. 10:46.

Glube, N., E. Closs, and P. Langguth. 2007. OCTN2-mediated carnitine uptake in a newly discovered human proximal tubule cell line (Caki-1). Mol. Pharm. 4:160-168.

Guzelbektes, H., I. Sen, M. Ok, P. D. Constable, M. Boydak, and A. Coskun. 2010. Serum amyloid A and haptoglobin concentrations and liver fat percentage in lactating dairy cows with abomasal displacement. J. Vet. Intern. Med. 24:213-219.

Hollmann, M., I. Miller, K. Hummel, S. Sabitzer, B. U. Metzler-Zebeli, E. Razzazi-Fazeli, and Q. Zebeli. 2013. Downregulation of cellular protective factors of rumen epithelium in goats fed high energy diet. PLoS ONE 8:e81602.

Invernizzi, G., A. Naeem, and J. J. Loor. 2012. Short communication: Endoplasmic reticulum stress gene network expression in bovine mammary tissue during the lactation cycle. J. Dairy Sci. 95:2562-2566.

Jørgensen, H. B., B. Buitenhuis, C. M. Røntved, L. Jiang, K. L. Ingvartsen, and P. Sorensen. 2012. Transcriptional profiling of the bovine hepatic response to experimentally induced $E$. coli mastitis. Physiol. Genomics 44:595-606.

Karin, M., and M. Delhase. 2000. The I kappa B kinase (IKK) and NF-kappa B: Key elements of proinflammatory signalling. Semin. Immunol. 12:85-98.

Keller, J., R. Ringseis, A. Koc, I. Lukas, H. Kluge, and K. Eder. 2012. Supplementation with L-carnitine downregulates genes of the ubiquitin proteasome system in the skeletal muscle and liver of piglets. Animal 6:70-78.

Lahjouji, K., G. A. Mitchell, and I. A. Qureshi. 2001. Carnitine transport by organic cation transporters and systemic carnitine deficiency. Mol. Genet. Metab. 73:287-297.

Loor, J. J., H. M. Dann, R. E. Everts, R. Oliveira, C. A. Green, N. A. Guretzky, S. L. Rodriguez-Zas, H. A. Lewin, and J. K. Drackley. 2005. Temporal gene expression profiling of liver from periparturient dairy cows reveals complex adaptive mechanisms in hepatic function. Physiol. Genomics 23:217-226.

Luci, S., S. Geissler, B. König, A. Koch, G. I. Stangl, F. Hirche, and K. Eder. 2006. PPAR $\alpha$ agonists up-regulate organic cation transporters in rat liver cells. Biochem. Biophys. Res. Commun. 350:704-708.

Luo, H., Y. Zhang, H. Guo, L. Zhang, X. Li, R. Ringseis, G. Wen, D. Hui, A. Liang, K. Eder, and D. He. 2014. Transcriptional regulation of the human, porcine and bovine OCTN2 gene by PPARo via a conserved PPRE located in intron 1. BMC Genet. 15:90.
Moyes, K. M., J. K. Drackley, D. E. Morin, S. L. Rodriguez-Zas, R. E. Everts, H. A. Lewin, and J. J. Loor. 2010. Mammary gene expression profiles during an intramammary challenge reveal potential mechanisms linking negative energy balance with impaired immune response. Physiol. Genomics 41:161-170.

Plaizier, J. C., D. O. Krause, G. N. Gozho, and B. W. McBride. 2008. Subacute ruminal acidosis in dairy cows: the physiological causes, incidence and consequences. Vet. J. 176:21-31.

Schlegel, G., J. Keller, F. Hirche, S. Geißler, F. J. Schwarz, R. Ringseis, G. I. Stangl, and K. Eder. 2012. Expression of genes involved in hepatic carnitine synthesis and uptake in dairy cows in the transition period and at different stages of lactation. BMC Vet. Res. 8:28.

Tamai, I., R. Ohashi, J. Nezu, H. Yabuuchi, A. Oku, M. Shimane, Y. Sai, and A. Tsuji. 1998. Molecular and functional identification of sodium ion-dependent, high affinity human carnitine transporter OCTN2. J. Biol. Chem. 273:20378-20382.

Thering, B. J., M. Bionaz, and J. J. Loor. 2009. Long-chain fatty acid effects on peroxisome proliferator-activated receptor-alpharegulated genes in Madin-Darby bovine kidney cells: Optimization of culture conditions using palmitate. J. Dairy Sci. 92:2027-2037.

Vallabhapurapu, S., and M. Karin. 2009. Regulation and function of NF- $\kappa \mathrm{B}$ transcription factors in the immune system. Annu. Rev. Immunol. 27:693-733.

Vaz, F. M., and R. J. Wanders. 2002. Carnitine biosynthesis in mammals. Biochem. J. 361:417-429.

Vels, L., C. M. Rontved, M. Bjerring, and K. L. Ingvartsen. 2009. Cytokine and acute phase protein gene expression in repeated liver biopsies of dairy cows with a lipopolysaccharide-induced mastitis. J. Dairy Sci. 92:922-934.

Wen, G., R. Ringseis, and K. Eder. 2010. Mouse OCTN2 is directly regulated by peroxisome proliferator-activated receptor a (PPAR $\alpha)$ via a PPRE located in the first intron. Biochem. Pharmacol. 79:768-776.

Zebeli, Q., and B. U. Metzler-Zebeli. 2012. Interplay between rumen digestive disorders and diet-induced inflammation in dairy cattle. Res. Vet. Sci. 93:1099-1108.

Zhou, X., G. Wen, R. Ringseis, and K. Eder. 2014. Short communication: The pharmacological peroxisome proliferator-activated receptor a agonist WY-14,643 increases expression of novel organic cation transporter 2 and carnitine uptake in bovine kidney cells. J. Dairy Sci. 97:345-349. 